http://jmscr.igmpublication.org/home/ ISSN (e)-2347-176x ISSN (p) 2455-0450 crossref DOI: https://dx.doi.org/10.18535/jmscr/v10i2.11

\title{
Role of Plasmapheresis in Acute Yellow Phosphorus Poisoning
}

\author{
Authors
}

\section{Dr Aparna Jayara and Dr Pratit Samdani}

\section{Introduction}

There are three major forms of elemental Phosphorus present in environment - white, red and black. Red phosphorus causes discoloration of white phosphorus leading to formation of yellow phosphorus. ${ }^{1}$ Yellow phosphorus is used in many industrial products like rodenticides, firework and fertilizers. $^{2}$ Its easy availability makes it impossible to prevent and control the incidence of phosphorus poisoning. Fatal dose of yellow phosphorus is $1 \mathrm{mg} / \mathrm{kg}^{3}$

In our case report we are presenting a case of 41year old male who developed acute liver dysfunction due to yellow phosphorus poisoning and was well managed with plasmapheresis.

\section{Case Report}

A 41-year-old male presented with ingestion of rodenticide poison in the form of a $15 \mathrm{gm}$ of paste containing $3 \%$ phosphorous. On evaluation, patient was hemodynamically stable with sinus tachycardia of $120 / \mathrm{min}$. There was no evidence of hepatic encephalopathy. His INR on admission was 1.61. Arterial blood gas (ABG) analysis was suggestive of compensated metabolic acidosis with serum bicarbonate of $11 \mathrm{mEq} / \mathrm{L}$. Later, on the same day patient developed hypotension and was started on vasopressor (i.e. noradrenaline infusion).
He was given full therapeutic dose of $\mathrm{N}$-Acetyl Cysteine (NAC) i.e. $150 \mathrm{mg} / \mathrm{kg}$ in $200 \mathrm{ml} \mathrm{D} 5$ over 1hour (as bolus), $50 \mathrm{mg} / \mathrm{kg}$ in $500 \mathrm{ml} \mathrm{D5}$ over 4 hours, $100 \mathrm{mg} / \mathrm{kg}$ in $1000 \mathrm{ml}$ D5 over 16 hours. Along with it, he was given Pantoprazole infusion, injection vitamin $\mathrm{K}$ and injection sodium bicarbonate infusion.

Abdominal sonography done on day 3, showed mildly thickened and oedematous gall bladder wall with pericholecystic fluid (image 1).

Abdominal sonography shows mildly thickened and edematous GB wall with pericholecystic fluid

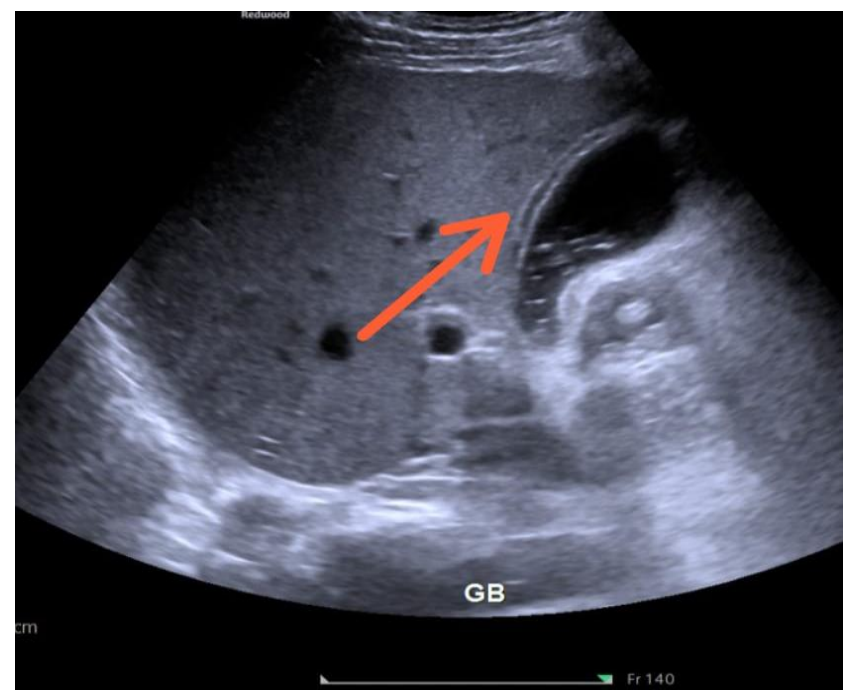

Image 1

On day 3 of toxin ingestion, his INR increased to 2.35. His SGPT was $61 \mathrm{U} / \mathrm{L}$, SGOT was $78 \mathrm{U} / \mathrm{L}$. Hispotassium level was $2.5 \mathrm{mmol} / \mathrm{L}$. 
2D Echocardiography was done, in which his Left Ventricular Ejection Fraction was $20 \%$ with marked generalized Left Ventricular hypokinesia and severe LV diastolic dysfunction.

On day 4, his INR further increased to3.56, SGPT and SGOT increased to $1142 \mathrm{U} / \mathrm{L}$ and $713 \mathrm{U} / \mathrm{L}$ respectively.

On day 5, his total leukocyte count (TLC) decreased to $1,500 / \mu \mathrm{L}$ and his platelet count decreased to $81000 / \mu \mathrm{L}$.

He was given 3 plasma exchange sessions on $5^{\text {th }}$, $6^{\text {th }}$ and $7^{\text {th }}$ day of his toxin ingestion.
On $6^{\text {th }}$ day, after 2 cycles of plasmapheresis, his INR reduced to 1.9 . TLC improved to $2,060 / \mu \mathrm{L}$, and SGPT and SGOT reduced to 711 and 1440 $\mathrm{U} / \mathrm{L}$ respectively.

His Noradrenaline infusion was completely tapered off on day8, after $3^{\text {rd }}$ cycle of plasma exchange. His $2 \mathrm{D}$ echo repeated on day 8 which showed his ejection fraction normalized to 45 to $50 \%$ with normal chamber dimensions

Patient was shifted to ward on day 10 of hospital admission.

Patient's Investigations on admission and on subsequent days are tabulated in chart (table 1).

Table 1

\begin{tabular}{|l|c|c|c|c|c|c|c|c|c|c|}
\hline & D1 & D2 & D3 & D4 & D5 & D6 & D7 & D8 & D9 & D10 \\
\hline HB $(\mathrm{gm} \%)$ & 14.4 & 14.8 & 14.2 & 13.5 & 14.4 & 13 & 12.1 & 10.3 & 10.5 & 11.5 \\
\hline WBC $(/ \mu \mathrm{L})$ & 6580 & 7530 & 6850 & 2880 & 1590 & 2060 & 8500 & 9800 & 11310 & 13110 \\
\hline PLT $(/ \mu \mathrm{L})$ & $3,17,000$ & $2,70,000$ & $2,00,000$ & $1,37,000$ & 81,000 & 70,000 & 83,000 & $1,14,000$ & $1,39,000$ & $1,95,000$ \\
\hline INR & 1.35 & & 2.35 & 3.56 & & 1.90 & & & 0.98 & 0.99 \\
\hline $\begin{array}{l}\text { POTASSIUM } \\
(\mathrm{mmol} / \mathrm{L})\end{array}$ & 4.86 & 3.72 & 2.5 & 2.67 & 3.33 & 3.28 & 2.82 & 4.31 & 3.85 & 5.14 \\
\hline SGOT $(\mathrm{U} / \mathrm{L})$ & 45 & 88 & 78 & 1142 & 2892 & 1440 & 327 & 165 & 133 & 107 \\
\hline SGPT(U/L) & 44 & 66 & 61 & 713 & 1443 & 711 & 315 & 237 & 205 & 189 \\
\hline BILIRUBIN $(\mathrm{mg} / \mathrm{dL})$ & 0.30 & 0.43 & 0.46 & 1.02 & 2.97 & 3.28 & 4.41 & 5.05 & 4.97 & 3.10 \\
\hline LACTATE(mmol/L) & 6.8 & 2.0 & 1.2 & & 1.7 & 1.5 & 1.1 & 0.6 & 0.9 & 0.8 \\
\hline
\end{tabular}

\section{Discussion}

Yellow Phosphorus causes toxicity by an exothermic reaction which leads to free radical production and affects multiple organs. ${ }^{4}$

Fernandez and Canizares in a case series of 15 patients in 1995 and Nalabothuetal in 2015 reported that yellow phosphorus ingestion carries a high mortality. 5,6

Usually during the first 48-72 h, only minimal gastrointestinal symptoms are manifested but subsequently acute liver failure ensues, progressing to multi-organ failure and death in extreme cases. 3,7

In our patient also, presenting symptoms were typically GI symptoms i.e. abdominal pain and vomiting.on evaluation he had tachycardia (pulse of 120 beats $/ \mathrm{min}$ ), a respiratory rate of 20 counts/min, and a blood pressure of $112 / 72 \mathrm{mmHg}$ in the supine position. Glasgow coma scale score was 15 with ABG showing compensated metabolic acidosis.
In Yellow Phosphorus poisoning, cardiac failure may ensue because of fluid and electrolyte loss (secondary to electrolyte abnormalities such as hypocalcemia and hyperkalemia) due to vomiting or diarrhoea or due to direct cardiac toxicity. ${ }^{8,9}$

In Our patient hypotension developed after admission and pump function of heart dropped to $20 \%$ with generalized LV hypokinesia. It was managed with IV fluids was vasopressors.

There is no specific antidote for yellow phosphorus poisoning. Gastric lavage with potassium permanganate converts the phosphorus to relatively harmless oxides. $^{[5]}$ Careful monitoring of liver and kidney function is required. Liver transplantation has been done in suitable candidates for acute hepatic failure. ${ }^{10}$

Studies have shown no clear benefit from $\mathrm{N}$-acetyl cysteine, corticosteroids, or exchange transfusion. $^{11}$

Our patient was given $\mathrm{N}$-acetyl cysteine on the day of admission but his liver function and INR 
kept on deteriorating, a sharp increase being seen on $4^{\text {th }}$ day, so from $5^{\text {th }}$ day to $7^{\text {th }}$ day he was given 3 cycles of plasmapheresis and by the second cycle of plasmapheresis i.e. on $6^{\text {th }}$ day his laboratory investigations including INR started coming back to normal, and his general condition started improving. Plasmapheresis was given by replacing full plasma volume (calculated on the basis of body weight and hematocrit) with fresh frozen plasma.

A study by Varghese $\mathrm{J}$ etal ${ }^{12}$, Matthew $\mathrm{J}$ etal ${ }^{13}$ and Angraje $\mathrm{S}$ etal ${ }^{14}$ also support therapeutic plasma exchange in management of yellow phosphorus poisoning with remarkable improvement in outcomes.

\section{Conclusion}

Yellow phosphorus poisoning is a big threat as suicide weapon because of its wide use in manufacture of multiple industrial products. Development of resistance of rodents to warfarin makes use of yellow phosphorus more prevalent. Though the ideal way to deal with this problem will be to discourage its use as an ingredient of rodenticide and to look for other alternatives. Clinicians should be aware of its toxicity and use of plasmapheresis in early stages should be encouraged in management of acute yellow phosphorus poisoning.

\section{References}

1. Brent $\mathrm{J}$, Wallace KL, Burkhart KK. Phosphorus. In: Brent J, Wallace KL, Burkhart KK, Phillips SD, Donovan JW, editors. Critical Care Toxicology Diagnosis and Management of the Critically Poisoned Patient. Philadelphia, PA: Elsevier Mosby; 2005. pp. 851-61. [Google Scholar]

2. Tenenbein M. Position statement: Whole bowel irrigation. American Academy of Clinical Toxicology; European Association of Poisons Centres and Clinical Toxicologists. J Toxicol Clin Toxicol
1997;35:753-62.

[PubMed]

[Google

Scholar]

3. Mauskar A, Mehta K, Nagotkar L, Shanbag P. Acute hepatic failure due to yellow phosphorus ingestion. Indian $\mathrm{J}$ Pharmacol 2011;43:355-6. [PUBMED] [Full text]

4. Mishra AK, Devakiruba NS, Jasmine S, Sathyendra S, Zachariah A, Iyadurai R. Clinical spectrum of yellow phosphorous poisoning in a tertiary care centre in South India: A case series. Trop Doct 2016. pii: 0049475516668986

5. Fernandez OU, Canizares LL. Acute hepatotoxicity from ingestion of yellow phosphorus-containing fireworks. J Clin Gastroenterol 1995;21:139-42.

6. Nalabothu $\mathrm{M}$, Monigari $\mathrm{N}$, Acharya $\mathrm{R}$. Clinical profi le and outcomes of rodenticide poisoning in tertiary care hospital. Int J Sci Res Publ 2015; 5:1-12. Available

from: http://www.ijsrp.org/research-paper0815/ijsrp-p4442.pdf. [Last accessed on 2016 Jan 05]. ^

7. Karanth S, Nayyar V. Rodenticide-induced hepatotoxicity. J Assoc Physicians India 2003;51:816-7. [PUBMED]

8. Ravikanth R, Sandeep S, Phillip B, Acute Yellow Phosphorus Poisoning Causing Fulminant Hepatic Failure with Parenchymal Hemorrhages and Contained Duodenal Perforation Indian $\mathrm{J}$ Crit Care Med. 2017 Apr; 21(4): 238-242.

9. Talley RC, Linhart JW, Trevino AJ, Moore L, Beller BM. Acute elemental phosphorus poisoning in man: Cardiovascular toxicity. Am Heart J. 1972;84:139-40. [PubMed] [Google Scholar]

10. Santos O, Restrepo JC, Velasquez L, Castano J, Correa G, Sepulveda E, et al. Acute liver failure due to white phosphorus ingestion. Ann Hepatol. 2009;8:162-5. [PubMed] [Google Scholar]

11. Marin GA, Montoya CA, Sierra JL, Senior JR. Evaluation of corticosteroid and 
exchange-transfusion treatment of acute yellow-phosphorus intoxication. $N$ Engl $J$ Med. 1971;284:125-8. [PubMed] [Google Scholar]

12. Varghese J, Joshi V, Bollipalli MK, Malleeswaran S, Patcha R, Nair H, Vij V, Sachan D, Subramanian P, Jain M, Venkataraman J. Role of therapeutic plasma exchange in acute liver failure due to yellow phosphorus poisoning. Indian $\mathrm{J}$ Gastroenterol. 2020 Dec;39(6):544-549. doi: 10.1007/s12664-020-01095-y. Epub 2021 Jan 6. PMID: 33409946; PMCID: PMC7787244.

13. Mathew J, Gnanaraj J, Basavarajegowda A, Venkateswaran R. Plasmapheresis in lethal yellow phosphorus poisoning: a scope for recovery. BMJ Case Rep. 2021 Apr 21;14(4):e239676. doi: 10.1136/bcr-2020239676. PMID: 33883110; PMCID: PMC8061805.

14. https://www.kireports.org/article/S24680249(20)30532-5/pdf cited on 18th nov 2021. 